\title{
Relationship between pollen morphology and chromosome numbers in Brazilian species of Lippia $\mathbf{L}$. (Verbenaceae)
}

\author{
SAULO M. SOUSA ${ }^{1}$, PATRÍCIA M.O. PIERRE ${ }^{2}$, GIOVANA A. TORRES ${ }^{3}$, \\ LISETE C. DAVIDE ${ }^{3}$ and LYDERSON F. VICCINI ${ }^{1}$ \\ ${ }^{1}$ Instituto de Ciências Biológicas, Departamento de Biologia, Laboratório de Genética, \\ Universidade Federal de Juiz de Fora (UFJF), Campus Universitário, Bairro Martelos, 36036-900 Juiz de Fora, MG, Brasil \\ ${ }^{2}$ Laboratório de Biologia Celular, Universidade Federal de Santa Catarina (UFSC), \\ Campus Universitário Curitibanos, Rodovia Ullysses Gaboardi Km 3, Caixa Postal 101, 89520-000 Curitibanos, SC, Brasil \\ ${ }^{3}$ Departamento de Biologia, Laboratório de Citogenética, Universidade Federal de Lavras (UFLA), \\ Campus Universitário, s/n, 37200-000 Lavras, MG, Brasil
}

Manuscript received on February 1, 2011; accepted for publication on July 22, 2011

\begin{abstract}
The pollen morphology and exine structure of 17 species of Lippia L. were investigated in this work using light and scanning electron microscopy. Among the species studied, 14 showed tricolporate pollen grains, two had tri- and tetracolporate pollen grains and a single species exhibited, only tetracolporate pollen. The amb ranged from triangular to square, and the shape varied from oblate-spheroidal to prolate-spheroidal. Three different types of exine ornamentation were observed: psilate, scabrate and perforate. In addition to morphological data, we found positive association between the chromosome numbers and size of pollen grains, and also between the length and width of the colpi. The results indicate that the characteristics of pollen grains in Lippia may be used as an additional taxonomic character of the genus.
\end{abstract}

Key words: chromosome numbers, Lippia, palynology, palynomorphology, pollen, Verbenaceae.

\section{INTRODUCTION}

Verbenaceae is a large-sized group of flowering plants included in the Asterids clade (Euasterids I), Lamiales (APG III 2009). It has around 36 genera with approximately 1,035 species (Judd et al. 2007).

The family is characterized mostly by wood habit with shrubs or trees, zygomorphic flowers, androecium didynamous, two carpels, ovary generally four loculed with terminal or subterminal style and a drupe or nutlets as fruits (Moldenke 1965). Many taxonomists have proposed different systems of classification and delimitation for

Correspondence to: Saulo Marçal de Sousa

E-mail: saulo_marcal@yahoo.com.br various genera, species and subspecies in the family, thus indicating problems in taxonomy (Caro 1981, Cronquist 1981, Howard 1989, Cantino 1990, Salimena 2000, Sanders 2001).

Several authors have investigated pollen structure of the family since palynology has been considered an useful tool to discriminate among closely related taxa (Erdtman 1945, 1969, Zaffar et al. 2006, Munsif et al. 2007, Perveen and Qaiser 2007). Nevertheless, only Raj (1983) used light micrscopy (LM), transmission electron microscopy (TEM) and scanning electron microscopy (SEM) data to compare 228 species belonging to 68 genera of Verbenaceae sensu lato. According to Sanders 
(2001), after a cladistic re-evaluation of phenetic analysis of pollen characters reported by Raj (1983), Verbenaceae sensu strictu pollen can be described as suboblate to prolate, radially symmetrical, generally tricolporate (tripororate or tricolpate in a few genera, or rarely with four-five independent apertures ). The colpi are usually long, narrow, ends tapering, equatorially constricted with a thickened margin. Ora is usually elongated at right angles to the colpi (lalongate) and the exine is tectate-perforate, with supratectal processes lacking, except for few genera.

Lippia, second largest genus of Verbenaceae, includes around 200 species of herbs, shrubs and small trees distributed throughout South and Central America and tropical Africa (Judd et al. 2007, Sanders 2001). Although many species of this genus are important sources of chemistry constituents for pharmaceutical, food and cosmetic industry, few studies have been done in order to investigate biological aspects of those plants (Pascual et al. 2001). Taxonomically, many problems regarding the species delimitation have been reported due to the lack of good taxonomic characters and several synonymies, homonymies and infraspecific taxa (Salimena and Romero 1999, Salimena and Silva 2002, Viccini et al. 2005). Therefore, revisions using additional data are necessary to better characterize Lippia species. Palynological characters, for instance, have been described only for five species of Lippia (Raj 1983). Here we described, for the first time, the palynomorphology of 17 Brazilian species of Lippia by LM and SEM and also discussed the taxonomic implications of those data.

\section{MATERIALS AND METHODS}

\section{Plant MATERIAL}

Floral buds of 17 Lippia species were obtained from the germplasm collection of Universidade Federal de Juiz de Fora, Minas Gerais, Brazil. Origin place and voucher number, as well as chromosome number of the species studied are presented in Table I. The species are native from the "Campos Rupestres" from Espinhaço Range of Minas Gerais (MG) state, Brazil, with exception of Lippia alba that is a cultivated species. The vouchers are deposited at the Herbarium CESJ of the Universidade Federal de Juiz de Fora.

PALINOLOGY

Pollen grains of the 17 taxa were examined under light microscope (LM) and scanning electron microscope (SEM).

For the LM, polliniferous material was placed in glacial acetic acid solution for three minutes and then acetolysed according to Erdtman (1960). Slides were mounted with glycerin jelly and examined using a BX 51 Olympus microscopy. The pollen material and slides were stored in Biology Department of Universidade Federal de Juiz de Fora.

For SEM analysis, polliniferous material was dehydrated in a graded acetone series, dried to the critical point and attached to stubs with double-faced sellotape. The stubs were gold coated in a B sputter for 15 minutes and representative pollen grains were photographed at various magnifications in a LEO Evo 40 XVP scanning electron microscope at Universidade Federal de Lavras, Minas Gerais Brazil.

Pollen terminology follows Faegri and Iversen (1975) and Punt et al. (2007).

\section{STATISTICAL ANALISYS}

Pollen diameters were obtained from at least 20 acetolysed samples while for other characters 10 samples were analyzed. All measures were obtained using Image Pro Plus software (Media Cybernetics $^{\mathrm{TM}}$, Silver Spring. MD, USA). Regression analysis was performed between chromosome number and polar axis diameter, equatorial diameter, colpus length and colpus width. The analyses were done using GENES statistical package (Cruz 2006; www.ufv.br/dbg/ genes/genes.htm) 
TABLE I

Origin, voucher number and chromosome number of 17 Lippia species.

\begin{tabular}{|c|c|c|}
\hline Species & Origin place and voucher number & $2 n$ \\
\hline \multicolumn{3}{|l|}{ Zapania Schauer section } \\
\hline Lippia alba (Mill.) N.E.Br. & Juiz de Fora-MG (47.724) & $30^{*}$ \\
\hline Lippia aristata Schauer & Diamantina-MG (47.610) & $24 * * *$ \\
\hline Lippia corymbosa Cham. & Diamantina-MG (47.523) & $28 * *$ \\
\hline Lippia diamantinensis Glaz. & Diamantina-MG (34.734) & $52 * *$ \\
\hline Lippia hermanioides Cham. & Serra do Cipó-MG (34.739) & $26 * *$ \\
\hline Lippia lacunosa Mart. \& Schauer & Diamantina-MG (42.705) & $56 * *$ \\
\hline Lippia rotundifolia Cham. & Diamantina-MG (34.338) & $56 * *$ \\
\hline Lippia rubella Moldenke & Diamantina-MG (42.706) & $20 * *$ \\
\hline \multicolumn{3}{|l|}{ Rhodolippia Schauer section } \\
\hline Lippia florida Cham. & Diamantina-MG (34.738) & $24 * *$ \\
\hline Lippia lupulina Cham. & Diamantina-MG (34.742) & $28 * *$ \\
\hline Lippia pseudo-thea Schauer & Diamantina-MG (34.340) & $26^{* *}$ \\
\hline Lippia rosella Moldenke & Diamantina-MG (34.746) & $28 * *$ \\
\hline \multicolumn{3}{|l|}{ Goniostachyum Schauer section } \\
\hline Lippia martiana Schauer & Serra do Cipó-MG (34.321) & $24 * * *$ \\
\hline Lippia pohliana Schauer & Diamantina-MG (39.360) & $24 * *$ \\
\hline Lippia salvifolia Cham. & Serra do Cipó (37.456) & $24 * * *$ \\
\hline Lippia sidoides Cham. & Serra do Cipó-MG (34.737) & $24 * *$ \\
\hline \multicolumn{3}{|l|}{ Dioicolippia Troncoso section } \\
\hline Lippia filifolia Mart. \& Schauer & Diamantina-MG (34.740) & $24 * *$ \\
\hline
\end{tabular}

* Bose and Choudhury (1960), ${ }^{* *}$ Viccini et al. (2005), ${ }^{* * *}$ Campos et al. 2011.

\section{RESULTS AND DISCUSSION}

The first report about palynological data of 17 Lippia species indicate that pollen grains in Lippia are monads, mainly tri-colporate (some taxa have also tetra-colporate grains), oblate-spheroidal to prolate-spheroidal, with polar axis varying from 17.45 to $40.32 \mu \mathrm{m}$ and equatorial diameter from 17.27 to $40.21 \mu \mathrm{m}$ (Table II, Figures 1 and 2). The amb shape is mainly triangular with some taxa showing triangular and square grains (Figures 1 and 2). There are three principal patterns of exine ornamentation in the genus: perforate, scabrate and psilate (Figure 3). Variation on perforation density among taxa was observed such as $L$. corymbosa, $L$. hermanioides and L. rotundifolia that showed more perforations than other species with perforate exine, L. filifolia, L. lupulina, L. pohliana, L. pseudothea and L. rosella, (Figure 3 A-D). Our morphological data were very similar to those reported by Raj (1983). According to this author, the genus shows elliptic pollen grains in an equatorial view, with triangular amb, equatorial contour of mesocolpia straight to convex, occasionally concave, with the $\mathrm{P}$ axis varying from 21 to $38 \mu \mathrm{m}$ and $\mathrm{E}$ axis varying from 18 to $35 \mu \mathrm{m}$. 
TABLE II

Pollen morphological data (mean values and standard deviations in $\mu \mathrm{m}$ ) of Lippia species. $\mathbf{E}=$ equatorial diameter, $\mathbf{P}=$ polar axis.

\begin{tabular}{|c|c|c|c|c|}
\hline Species & $\mathbf{P}$ & $\mathbf{E}$ & $\mathbf{P} / \mathbf{E}$ & Pollen shape \\
\hline L. alba* & $33.72 \pm 1.99$ & $34.34 \pm 1.97$ & 0.97 & Oblate spheroidal \\
\hline L. aristata* & $26.49 \pm 2.12$ & $26.41 \pm 1.98$ & 1.00 & Prolate spheroidal \\
\hline L. corymbosa* & $29.67 \pm 1.59$ & $29.67 \pm 1.97$ & 1.02 & Prolate spheroidal \\
\hline L. diamantinensis* & $34.46 \pm 3.24$ & $30.56 \pm 1.9$ & 1.12 & Prolate spheroidal \\
\hline L. filifolia $* * * *$ & $26.67 \pm 1.86$ & $25.59 \pm 1.18$ & 0.96 & Oblate spheroidal \\
\hline L. florida** & $31.81 \pm 2.45$ & $28.69 \pm 3.17$ & 1.10 & Prolate spheroidal \\
\hline L. hermanioides * & $26.02 \pm 1.82$ & $26.23 \pm 2.06$ & 0.99 & Oblate spheroidal \\
\hline L. lacunosa * & $38.41 \pm 4.13$ & $37.3 \pm 3.98$ & 1.13 & Prolate spheroidal \\
\hline L. lupulina** & $31.8 \pm 2.08$ & $32.27 \pm 2.48$ & 0.98 & Oblate spheroidal \\
\hline L. martiana $* * *$ & $23.87 \pm 3.12$ & $24.93 \pm 3.01$ & 0.96 & Oblate spheroidal \\
\hline L. pohliana $* * *$ & $23.23 \pm 1.85$ & $22.23 \pm 2.04$ & 1.04 & Prolate spheroidal \\
\hline L. pseudothea** & $26.34 \pm 1.18$ & $24.46 \pm 0.87$ & 1.07 & Prolate spheroidal \\
\hline L. rosella $* *$ & $30.00 \pm 1.62$ & $28.99 \pm 1.30$ & 1.03 & Prolate spheroidal \\
\hline L. rotundifolia* & $40.32 \pm 3.43$ & $40.21 \pm 2.87$ & 1.10 & Prolate spheroidal \\
\hline L. rubella* & $17.45 \pm 1.45$ & $17.27 \pm 1.39$ & 1.01 & Prolate spheroidal \\
\hline L. salviifolia*** & $27.31 \pm 1.29$ & $27.42 \pm 1.41$ & 1.00 & Prolate spheroidal \\
\hline L. sidoides $* * *$ & $20.63 \pm 2.02$ & $20.68 \pm 2.12$ & 0.99 & Oblate spheroidal \\
\hline
\end{tabular}

* Section Zapania Schauer; ** Section Rhodolippia Schauer; *** Section Goniostachyum Schauer;

**** Section Dioicolippia Troncoso.

Regarding pollen size, apertures number and exine ornamentation, the section Zapania Schauer was the most diverse one. Out of the 17 taxa, $L$. rubella and L. rotundifolia, that belong to Zapania, showed the smallest and the biggest pollen grains, respectively (Table II, Figures 1 and 2). This section was the only one with three or four apertures while the other sections showed only three (Table III, Figure 1). In addition, only Zapania showed three types of ornamentation (Table IV-Figures 1, 2 and 3).

Higher variation in Zapania section has also been reported even with different approaches. Salimena (2000) described morphological variation, mainly for inflorescence pattern while Viccini et al. (2005) reported higher variation in chromosome numbers when compared with other sections. They observed the smallest ( $L$. rubella $2 \mathrm{n}=20$ ) and the highest (L. lacunosa and L. rotundifolia, both with
$2 n=26$ ) chromosome numbers in the genus,. These results taken together reinforce the hypothesis that Zapania is an inconsistent section that should be reviewed for better delimitation.

On the other hand, the species of Rhodolippia section seems to be very uniform considering the morphology, aperture number, size and exine ornamentation of the pollens grains. All species showed pollen with similar size, three apertures and perforate exine, except $L$. florida that has an exine psilate to scabrate (Tables II-IV, Figures 1, 2 and $3)$. These observations reinforce the consistence of the section as proposed by Salimena (2000) and Viccini et al. (2005).

Regarding Goniostachyum and Dioicolippia, the species showed similar pollen size and three apertures (Tables II-IV, Figures 1, 2 and 3). Nevertheless, the species diverged in the exine 

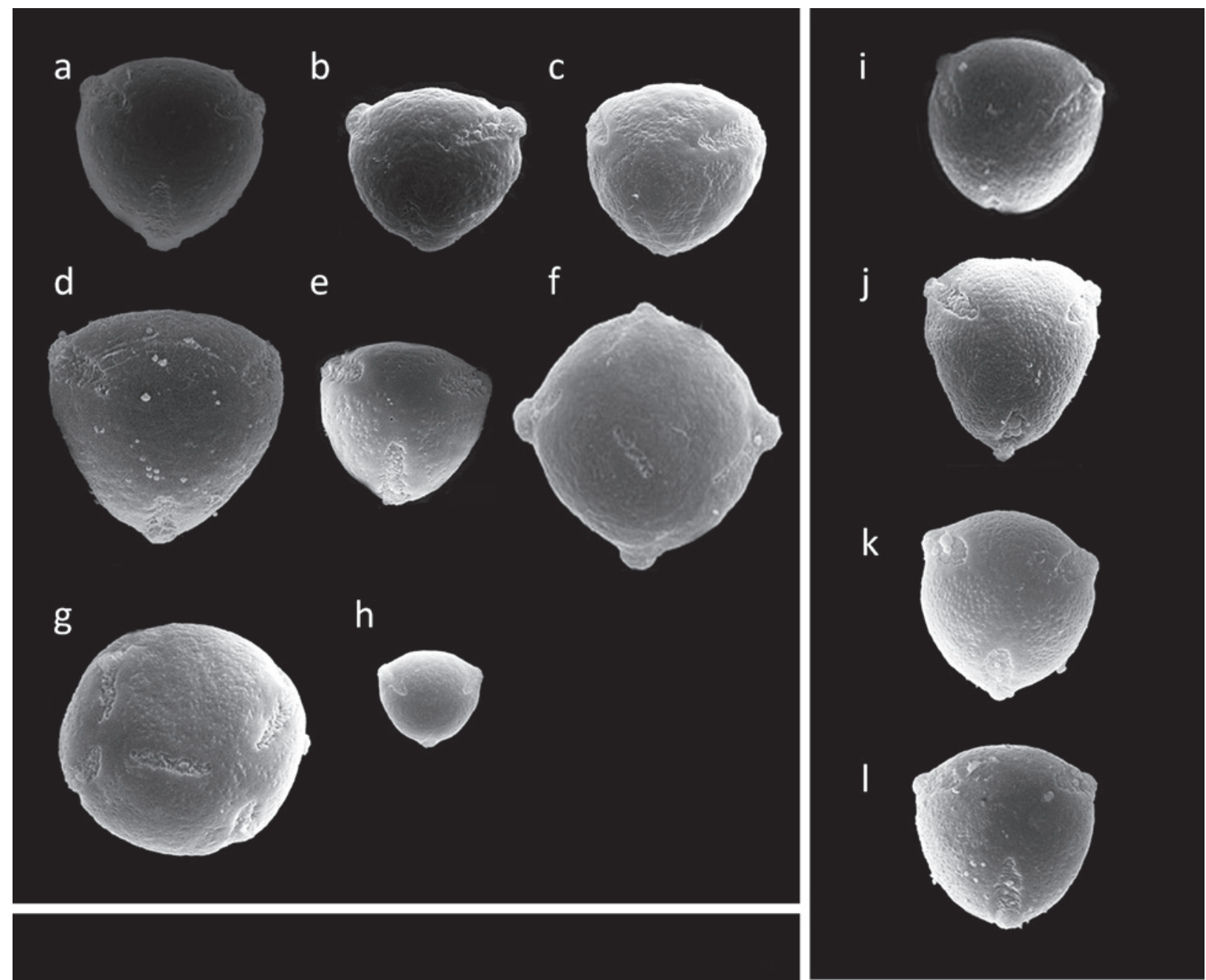

$\mathrm{m}$

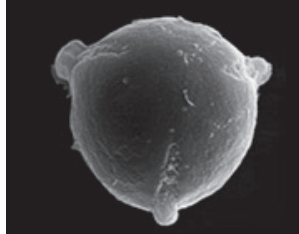

n

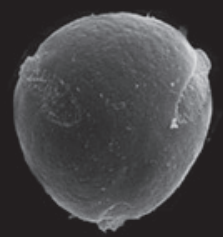

O

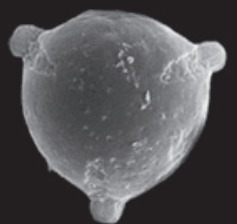

$p$

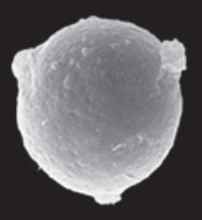

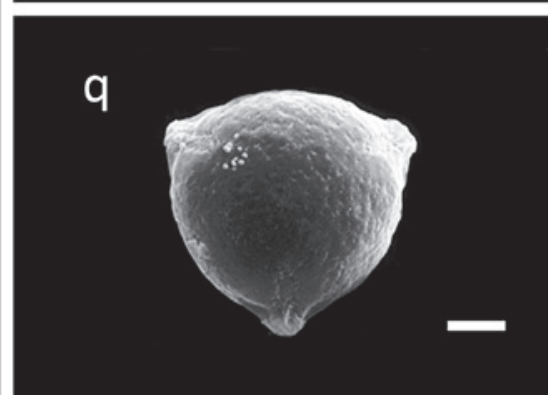

Fig. 1 - Pollen of 17 Lippia species in polar view. Zapania Schauer section: (a) L. alba, (b) L. aristata, (c) L. corymbosa, (d) L. diamantinensis, (e) L. hermanioides, (f) L. lacunosa, (g) L. rotundifolia, (h) L. rubella; Rhodolippia Schauer section: (i) L. florida, (j) L. lupulina, (k) L. pseudothea, (l) L. rosella; Goniostachyum Schauersection: (m) L. martiana, (n) L. pohliana, (o) L. salviifolia, (p) L. sidoides; Dioicolippia Troncoso section: (q) L. filifolia. Bar $=8 \mu \mathrm{m}$.

ornamentation. The species from Goniostachyum showed psilate to scabrate exine and only L. pohliana exhibited one exine varying to psilate-perforate. The unique specie studied from Dioicholippia showed a perforate exine as it was observed in Rhodolippia (Table III, Figures 1, 2 and 3).

In addition to pollen morphology, we observed that pollen grain size, as well as the colpus length 

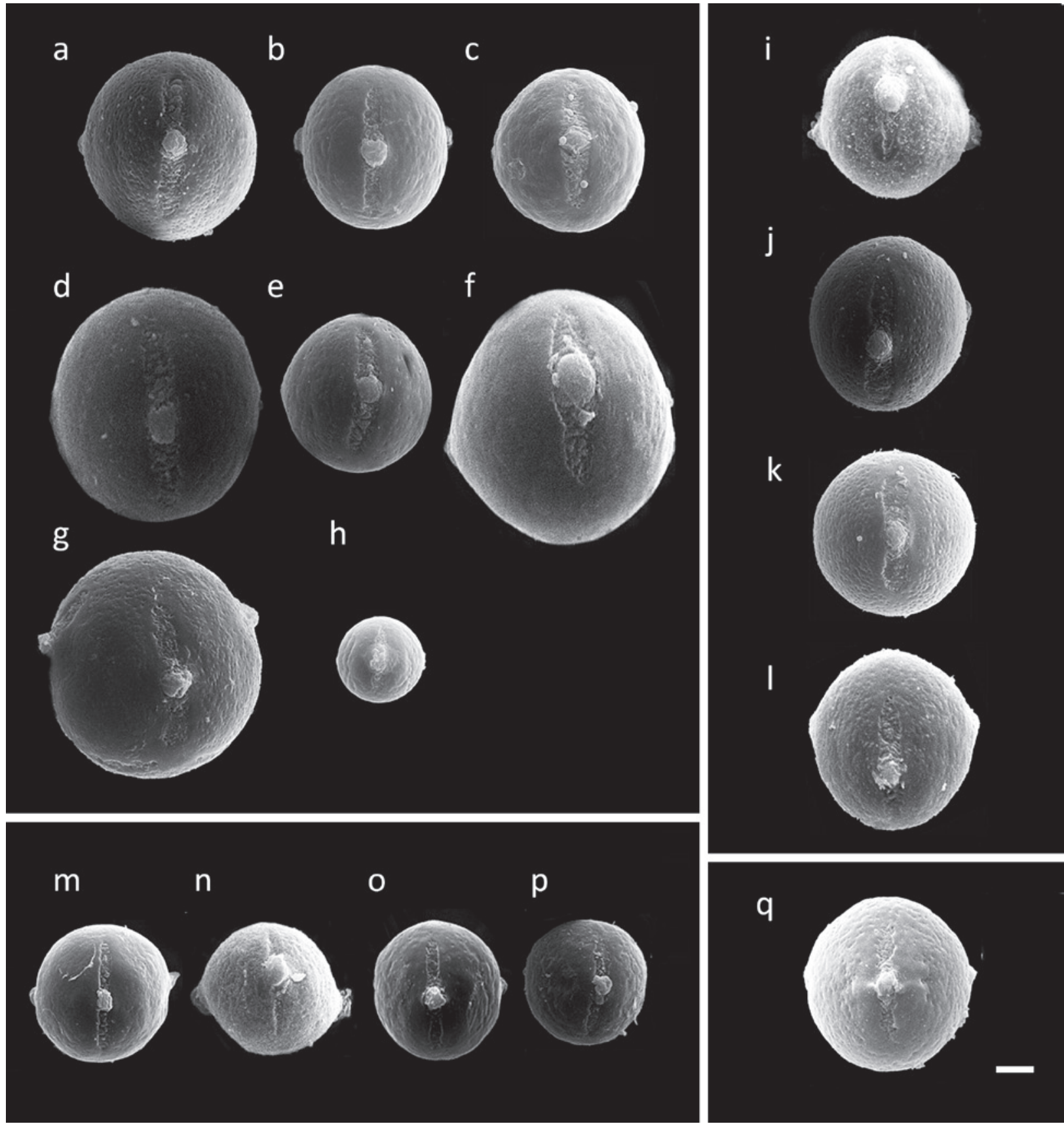

Fig. 2 - Pollen of 17 Lippia species in equatorial view. Zapania Schauer section: (a) L. alba, (b) L. aristata, (c) L. corymbosa, (d) L. diamantinensis, (e) L. hermanioides, (f) L. lacunosa, (g) L. rotundifolia, (h) L. rubella; Rhodolippia Schauer section: (i) L. florida, (j) L. lupulina, (k) L. pseudothea, (l) L. rosella; Goniostachyum Schauer section: (m) L. martiana, (n) L. pohliana, (o) L. salviifolia, (p) L. sidoides; Dioicolippia Troncoso section: (q) L. filifolia. $\mathrm{Bar}=8 \mu \mathrm{m}$.

and colpus width are strong related to ploidy. Species with small chromosome numbers showed smallest grains, while species with more chromosomes (polyploids) showed biggest grains and highest colpus length and colpus width (Figure 4). The chromosome number of Lippia species can be seen in Table I. Described as Gigas effect, Stebbins (1971) stated that polyploidy could 


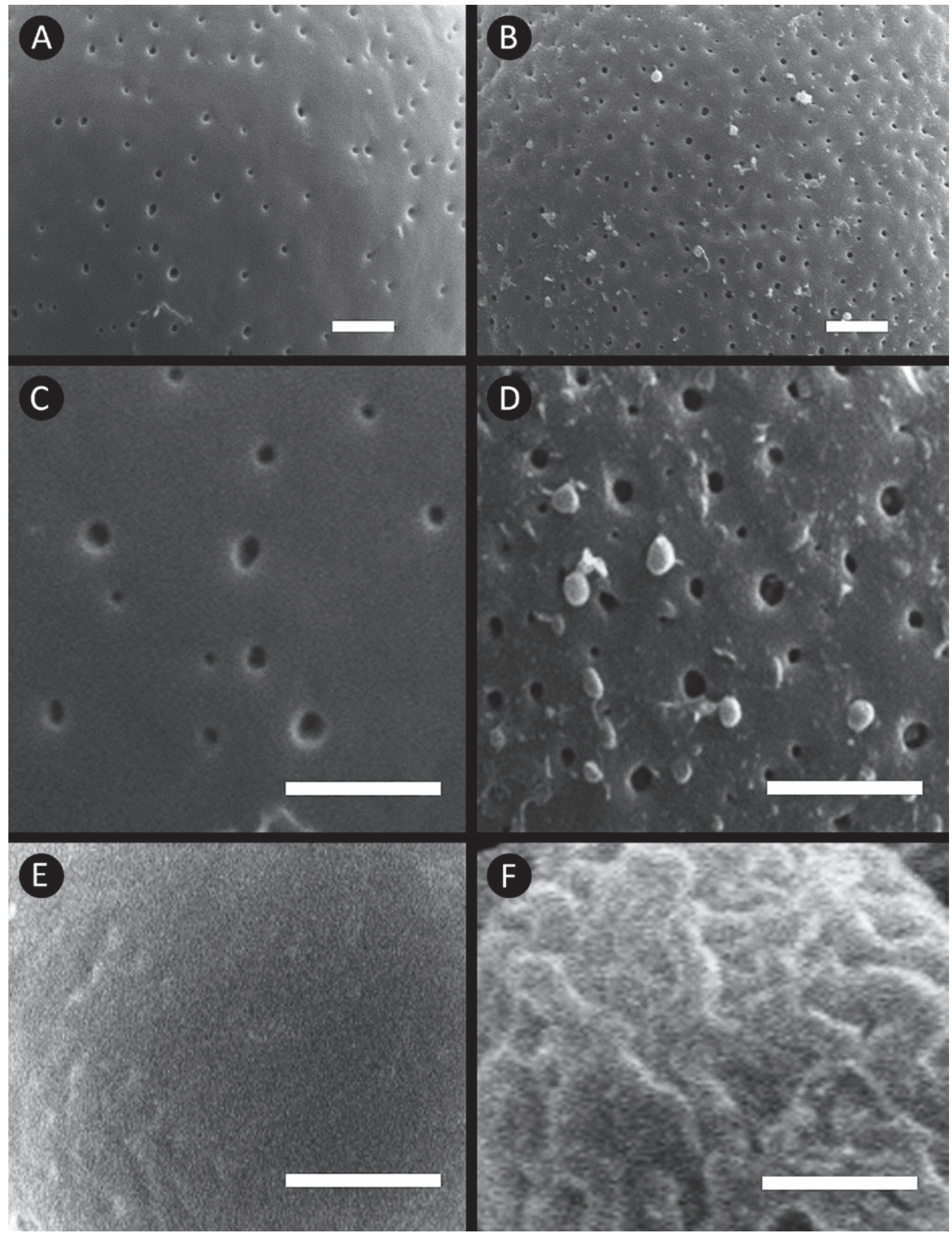

Fig 3 - Exine types in the genus Lippia. (A-B) perforate type, (C) perforate with few puncts per area, (D) perforate with many puncts per area, (E) psilate, (F) scabrate. Bars $=2 \mu \mathrm{m}$. 
TABLE III

Pollen morphological data (mean values and standard deviation in $\mu \mathrm{m})$ of Lippia species.

\begin{tabular}{|c|c|c|c|c|}
\hline Species & Endexine & Ectexine & Ornamentation & Aperture number \\
\hline L. alba* & $1.00 \pm 0.11$ & $1.04 \pm 0.13$ & Psilate to perforate & 3 \\
\hline L. aristata* & $0.68 \pm 0.18$ & $1.07 \pm 0.15$ & Scabrate & 3 \\
\hline L. corymbosa* & $0.70 \pm 0.21$ & $0.85 \pm 0.25$ & Perforate & 3 \\
\hline L. diamantinensis* & $0.74 \pm 0.13$ & $0.93 \pm 0.17$ & Psilate & $3-4$ \\
\hline L. filifolia $* * * *$ & $0.62 \pm 0.13$ & $0.92 \pm 0.17$ & Perforate & 3 \\
\hline L. florida** & $1.12 \pm 0.15$ & $0.91 \pm 0.13$ & Psilate to scabrate & 3 \\
\hline L. hermanioides* & $0.76 \pm 0.13$ & $0.79 \pm 0.15$ & Perforate & 3 \\
\hline L. lacunosa* & $0.94 \pm 015$ & $1.00 \pm 0.17$ & Psilate & $3-4$ \\
\hline L. lupulina** & $1.05 \pm 0.18$ & $1.08 \pm 0.23$ & Perforate & 3 \\
\hline L. martiana $* * *$ & $0.79 \pm 0.12$ & $0.92 \pm 0.13$ & Psilate & 3 \\
\hline L. pohliana*** & $0.69 \pm 0.12$ & $0.60 \pm 0.11$ & Psilate to perforate & 3 \\
\hline L. pseudothea** & $0.83 \pm 0.20$ & $0.83 \pm 0.21$ & Perforate & 3 \\
\hline L. rosella** & $1.09 \pm 0.18$ & $0.87 \pm 0.10$ & Perforate & 3 \\
\hline L. rotundifolia* & $0.87 \pm 0.11$ & $0.80 \pm 0.13$ & Perforate & 4 \\
\hline L. rubella* & $0.88 \pm 0.15$ & $0.81 \pm 0.16$ & Psilate to scabrate & 3 \\
\hline L. salviifolia $* * *$ & $0.68 \pm 0.17$ & $0.81 \pm 0.14$ & Psilate to scabrate & 3 \\
\hline L. sidoides $* * *$ & $0.70 \pm 0.16$ & $0.85 \pm 0.13$ & Psilate to scabrate & 3 \\
\hline
\end{tabular}

* Section Zapania Schauer; ** Section Rhodolippia Schauer; *** Section Goniostachyum Schauer;

**** Section Dioicolippia Troncoso.

cause an increase of cell size in plants what could lead to an increase of the size of some organs, like flowers and seeds. The positive relationship between ploidy level and pollen size has been reported for several plant genera either in natural or artificially induced polyploids (Katisiotis and Forsberg 2005, Celenk et al. 2008).

Relationship between genome size and cell size was also reported (Beaulieu et al. 2008) and can help to understand the positive correlation observed between pollen size and chromosome number. Considering that pollen grains have three nuclei (two vegetative and one generative), an increase of genome size could directly affect the pollen size. Knight et al. (2010) performed the regression analysis between pollen width and genome size for 464 species from different families observed that congeneric species tend to exhibit an increase of pollen width with the genome size increment. Regarding the genus Lippia, Campos et al. (2011), observed a positive correlation between chromosome number and DNA C-value for 28 species including the ones investigated in the present study. These observations in addition to the positive correlation between pollen size and chromosome number here observed corroborate that Lippia follow the same tendency previously reported by Knight et al. (2010).

It was also possible to observe that species with higher chromosome number exhibit higher number of apertures (Figure 4). Most of the species have pollen grains with three apertures, although species with more than $\mathrm{n}=15$ showed 3 and 4 or only 4 apertures, such as L. rotundifolia (Table III). The occurrence of pollen with variable number of aperture within the same species had already been reported in other groups and was defined as pollen heteromorphism (Till-Bottraud et al. 1995). The occurrence of pollen grains with different morphology, mainly regarding to aperture number, can be directly correlated with the pollen tube germination. Changes in the 
TABLE IV

Pollen morphological data (mean values and standard deviations of colpi in $\mu \mathrm{m}$ ) of Lippia species. Clg = colpus length, Clt $=$ colpus width.

\begin{tabular}{|c|c|c|}
\hline Species & Endexine & Ectexine \\
\hline L. alba* & $22.13 \pm 1.98$ & $2.87 \pm 0.20$ \\
\hline L. aristata* & $13.54 \pm 1.31$ & $2.11 \pm 0.25$ \\
\hline L. corymbosa* & $16.21 \pm 1.32$ & $2.01 \pm 0.12$ \\
\hline L. diamantinensis* & $24.95 \pm 1.13$ & $3.03 \pm 0.27$ \\
\hline L. filifolia**** & $15.32 \pm 1.33$ & $2.43 \pm 0.32$ \\
\hline L. florida** & $13.21 \pm 1.45$ & $2.32 \pm 0.21$ \\
\hline L. hermanioides* & $14.85 \pm 1.73$ & $2.46 \pm 0.31$ \\
\hline L. lacunosa* & $27.81 \pm 1.15$ & $3.23 \pm 0.40$ \\
\hline L. lupulina** & $15.21 \pm 1.18$ & $2.65 \pm 0.23$ \\
\hline L. martiana $* * *$ & $13.33 \pm 1.22$ & $2.21 \pm 0.21$ \\
\hline L. pohliana ${ }^{* * *}$ & $13.72 \pm 1.42$ & $2.25 \pm 0.10$ \\
\hline L. pseudothea** & $14.21 \pm 1.10$ & $2.11 \pm 0.13$ \\
\hline L. rosella** & $13.38 \pm 1.08$ & $2.02 \pm 0.15$ \\
\hline L. rotundifolia* & $28.85 \pm 0.11$ & $3.42 \pm 0.13$ \\
\hline L. rubella* & $12.74 \pm 1.34$ & $1.95 \pm 0.17$ \\
\hline L. salviifolia $* * *$ & $13.56 \pm 1.21$ & $1.98 \pm 0.22$ \\
\hline L. sidoides $* * *$ & $13.21 \pm 1.06$ & $2.00 \pm 0.32$ \\
\hline
\end{tabular}

* Section Zapania Schauer; ** Section Rhodolippia Schauer; *** Section Goniostachyum Schauer; **** Section Dioicolippia Troncoso.

aperture number could influence some parameters of pollen grain fitness (Dajoz et al. 1993). A good example has been observed in the genus Viola, where the aperture number is positively correlated with germination speed, but negatively associated with pollen life expectancy (Dajoz et al. 1993, TillBottraud et al. 1995). Among other models proposed to explain those observations, Till-Bottraud et al. (1994) predicts that pollen heteromorphism is an evolutionary stable strategy if there is a trade-off between germination speed and life-expectancy of pollen grain. Natural selection should favour many aperturate quickly germinating pollen grains when pollinators are abundant and longer-lived pollen grains when pollinators are scarce. We have observed that pollen grains of L. lacunosa with simultaneously tri and tetra-apertures, when germinated in vitro, showed different behavior. In general, pollens with
A

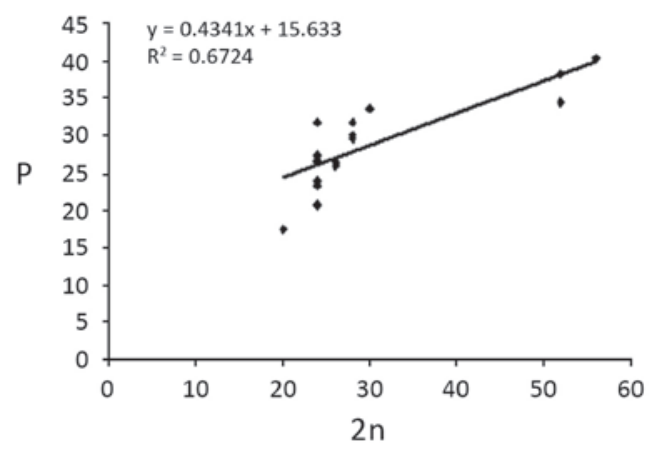

B

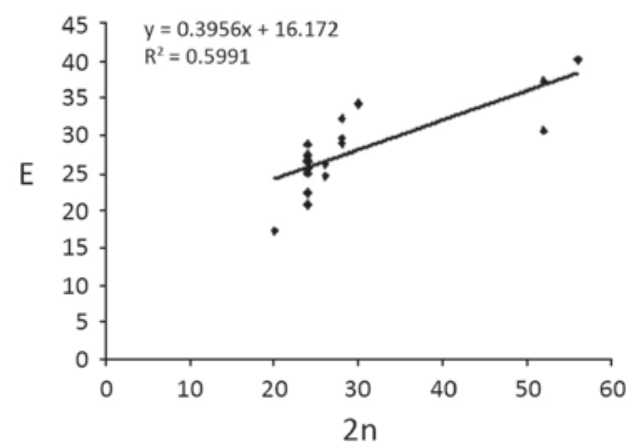

C

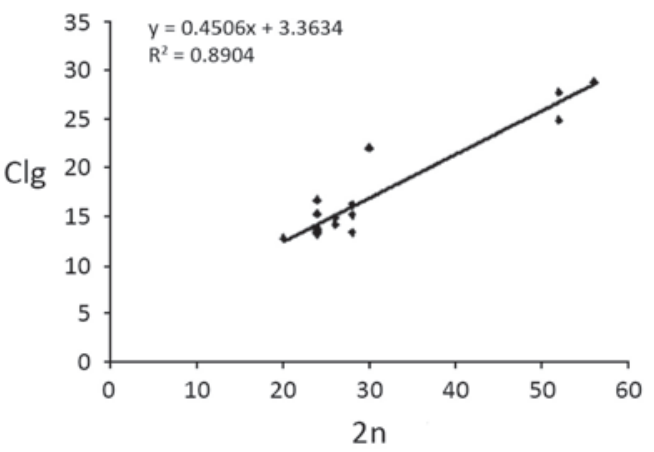

D

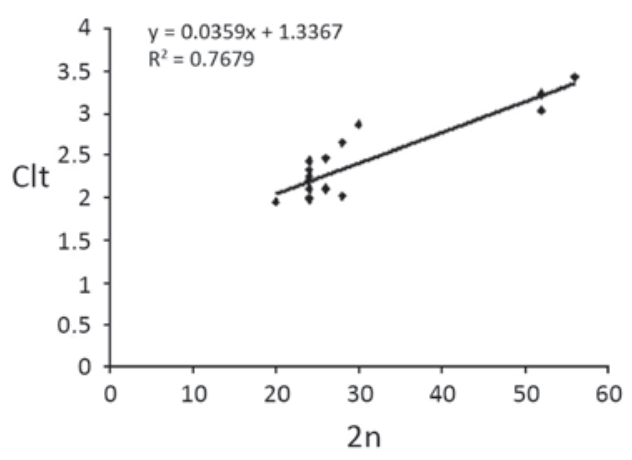

Fig. 4 - Relationship between chromosome number (2n) with: (A) polar axis diameter, (B) equatorial diameter, (C) colpus length and (D) colpus width. 
four aperture developed their pollen tube during the two firsts hours, while pollens with three apertures showed the same only after five hours (data not shown). Further studies with pollen germination and pollen viability should be made to better understand the influence of pollen heteromorphism on the pollination of the genus Lippia.

In conclusion, palynomorphological data revealed that in the genus Lippia, pollen size and colpus length/width can be directly associated with chromosome number and can also be used as an additional tool to establish evolutionary trends and taxonomic relationship among species.

\section{ACKNOWLEDGMENTS}

The authors thank Conselho Nacional de Desenvolvimento Científico e Tecnológico (CNPq), Coordenação de Aperfeiçoamento de Pessoal de Nível Superior (CAPES) and Fundação de Amparo à Pesquisa do Estado de Minas Gerais (FAPEMIG) for financial support and the Laboratory of Scanning Electron Microscopy and Ultrastructural Analysis (LME/UFLA)/FAPEMIG for SEM assistance.

\section{RESUMO}

A morfologia polínica e a estrutura da exina de 17 espécies de Lippia L. foram investigadas neste trabalho utilizando microscopia de luz e microscopia eletrônica de varredura. Dentre as espécies estudadas, 14 apresentaram grãos de pólens tricolporados, duas apresentaram pólens tri e tetracolporados e uma única espécie apresentou pólens tetracolporados. O âmbito variou de triangular a quadrado, e a forma variou de oblato-esferoidal à prolato-esferoidal. Três diferentes tipos de ornamentação da exina foram observados: psilada, escabrada e perfurada. Em adição aos dados morfológicos, encontramos associações positivas entre o número cromossômico e o tamanho dos grãos de pólen e também entre o comprimento e a larguara dos colpos. Os resultados indicaram que as características dos grãos de pólen no gênero Lippia podem ser utilizadas como um caracter taxonômico adicional do gênero.
Palavras-chave: número cromossômico, Lippia, palinologia, palinomorfologia, pólen, Verbenaceae.

\section{REFERENCES}

ANGiosperm Phylogeny Group. 2009. An update of the Angiosperm Phylogeny Group classification for the orders and families of flowering plants: APG III. Bot J Linn Soc 161: 105-121.

Beaulieu JM, Leitch IJ, Patel S, Pendharkar A And KNIGHT CA. 2008. Genome size is a strong predictor of cell size and stomatal density in angiosperms. New Phytol 179: 975-986.

Bose RB AND CHOudhury JK. 1960. Cytological studies in L. alba (Mill) N E Br. Bull BotSoc Bengal 14: 71-72

CAmpos JMS, Sousa SM, Silva PS, Pinheiro LC, SAMPaio F AND VICCINI LF. 2011. Chromosome numbers and DNA $\mathrm{C}$ values in the genus Lippia (Verbenaceae). Plant Syst Evol 291: 133-140.

CANTINO PD. 1990. The phylogenetic significance of stomata and trichomes in the Labiatae and Verbenaceae. Jour Arnold Arb 71: 323-370.

CARO J. 1981. Sistematización del gênero Acantholippia Grisebach (Verbenaceae) en las especies de la flora argentina. Dominguezia 3: 1-31.

Celenk S, Tarimcilar G, Bicakci A, Kaynak G and MALYER H. 2008. A palynological study of the genus Mentha L. (Lamiaceae). Bot J Linn Soc 157: 141-154.

CRONQUIST A. 1981. An integrated system of classification of flowering plants. New York, $1262 \mathrm{p}$.

CRUZCD. 2006. Programa GENES: Versão Windows, aplicativo computacional em genética e estatística. Viçosa, Brasil.

Dajoz I, TILl-BotTraud I And Gouyon PH. 1993. Pollen aperture polymorphism and gametophyte performance in Violla diversifolia. Evolution 47: 1080-1093.

ERdTMAn G. 1945. Pollen morphology and plant taxonomy. Labiatae, Verbenaceae and Avicenniaceae. Sven Bot Tidskr 39: 279-285.

ERDTMAN G. 1960. The acetolysis method. A revised description. Sven Bot Tidskr 54: 561-564.

ERDTMAN G. 1969. Handbook of palynology. Munksgaard, Copenhagen, $486 \mathrm{p}$.

FAEGRI K AND IVERSEN J. 1975. Textbook of pollen analysis, New York: Hafner Press.

HowARD RA. 1989. Verbenaceae. Fl Lesser Antilles 6: 212-244.

Judd WS, CAmpbell CS, Kellogg EA, Stevens PF AND DonoghuE MJ. 2007. Plant Systematics. 2002. A phylogenetic approach. Sinauer, Sunderland, $620 \mathrm{p}$.

KATISIOTIS A AND FORSBERG RA. 2005. Pollen grain size in four ploidy levels of genus Avena. Euphytica 83: 103-108.

Knight CA, Clancy RB, Gotzenberger L, DANN L AND BEAULIEU JM. 2010. On the relationship between pollen size and genome size. J Bot 2010: 1-7.

MOLDENKE HNA. 1965. Materials toward a monograph of the genus Lippia I. Phytologia 12: 6-71. 
Munsif S, Khan MA, AhMAd M, ZAFAR M, Shan GM AND YASmin G. 2007. Comparative Pollen Studies of the Genera Lantana, Verbena and Vitex of family Verbenaceae from Pakistan. Int J Agr Biol 9: 545-549.

Pascual me, Slowing K, Carretero E, Sánchez Mata D AND VILLAR A. 2001. Lippia: traditional uses, chemistry and pharmacology: a review. J Ethnopharmacol 6: 201-214.

PerveEn A AND QAISER M. 2007. Pollen flora of Pakistan-LIII. Verbenaceae. Pak J Bot 39: 663-669.

Punt W, Hoen PP, Blackmore S, Nilsson S and Thomas AL. 2007. Glossary of pollen and spore terminology. Rev Palaeobot Palynol 143: 1-81.

RAJ B. 1983. A contribution to the pollen morphology of Verbenáceae. Rev Palaeobot Palynol 39: 343-422.

SALIMENA FRG. 2000. Revisão taxonômica de Lippia L. sect. Rhodolippia Schauer (Verbenaceae). D. Sc. Thesis. Universidade de São Paulo.

SALIMENA FRG AND ROMERO MEM. 1999. Nuevos sinonimos para Lippia lasiocalycina (Verbenaceae). Hickenia 37: 129-132.
SALIMENA FRG AND Silva TRS. 2002. Novos sinônimos e tipificações em Lippia (Verbenaceae). Darwiniana 40: 33-41.

SANDERS RW. 2001. The genera of Verbenaceae in the southeastern United States. Harv Pap Bot 5: 303-358.

SteBbins GL. 1971. Chromosomal evolution in higher plants. London: Edward Arnold, 216 p.

Till-Bottraud I, Mignot A, DE Paepe R and Dajoz I. 1995. Pollen heteromorphism in Nicotiana tabacum (Solanaceae). Amer J Bot 82: 1040-1048.

TILl-BotTRAud I, VenABLE L, DAJOZ I AND GOUYON PH. 1994. Selection on pollen morphology: a game theory model. Am Nat 144: 395-411.

Viccini LF, Pierre PMO, PraÇA MM, Costa DCS, Romanel EC, Sousa SM, PeiXoto PHP AND SAlimena FRG. 2005. Chromosome numbers in the genus Lippia (Verbenaceae). Plant Syst Evol 256: 171-178.

ZAFFAR M, AhMEd M AND KHAN MA. 2006. Palynological studies of Verbenaceae from Margalla Hills, Islamabad, Pakistan. Pak J Plant Sci 12: 21-25. 